\title{
The Development History of the Yellow Book (Kitab Kuning) as Islamic Textbooks in Indonesia Based on the Philology Perspective
}

Rosidin Rosidin ${ }^{1 *}$, Fenty Andriani², Akhmad Nurul Kawakip ${ }^{3,}$ Moh. Mansur

Fauzi $^{4}$

\author{
${ }^{1}$ STAI Ma'had Aly Al-Hikam Malang, Indonesia \\ ${ }^{2}$ Institut Agama Islam Negeri (IAIN) Ponorogo, Indonesia \\ ${ }^{3}$ Universitas Islam Negeri (UIN) Maulana Malik Ibrahim Malang, Indonesia \\ ${ }^{4}$ STAI Ma'had Aly Al-Hikam Malang, Indonesia \\ *Corresponding author.Email: mohammed.rosidin@gmail.com
}

\begin{abstract}
This paper is examined the development history of the yellow book (kitab kuning) as Islamic textbooks in Indonesia from the perspective of philology. First, from the codicology perspective, the yellow book scattered in Indonesia since the $16^{\text {th }}$ to $21^{\text {st }}$ century had a consistent increase in terms of variations of scientific disciplines, the title of the book and media. The purpose of the yellow book originated from da'wah (Islamic call) material. It then became a lesson material in pesantren (Islamic boarding school) before being a reference in Bahtsul Masa'il (solving religious issues), lectures, legislation and the MUI (The Indonesian Council of Ulama) fatwa. Before being written by the Indonesian, the yellow book were originally written by foreigners, especially from the Middle East (Arabs, Persian). Second, from the textology perspective, the number of yellow book scripts has implications for the significance of the plural text criticism. The yellow book which has long been used by academic society, especially pesantren, shows the pragmatic side, reception aesthetics and reception dynamics in the text edition context. Third, transliteration and translation of the yellow book started from the hanging translation (terjemah gandul) method to interpret its original Arabic language by using the archipelago languages (Malay, Javanese, Sundanese, Madura) in the form of Arabic script (Pegon). Furthermore, transliteration and translation of yellow book are growing rapidly, especially from Arabic scripts to Latin script and from Arabic to Indonesian.
\end{abstract}

Keywords: The Yellow Book (Kitab Kuning), Development History, Philology, Codicology, Textology.

\section{INTRODUCTION}

Pesantren (Islamic boarding schools) are Indonesian indigenous Islamic education institutions spread across 34 provinces. Based on data statistics per 14 May 2021, the number of pesantren reached 26,974 units, santri mukim (the students who settled in a pesantren cottage environment) was 1,444,527 and santri non-mukim (did not settle in pesantren) were $1,202,556$, so totaling 2,647,083 santri. Provinces that have the highest pesantren are West Java (8,343 units, 148,987 santri mukim and 306,728 santri non-mukim); Banten (4,579 units, 60,897 mukim and 96,042 nonmukim); East Java (4,452 units, 323,293 mukim and 241.006 non-mukim); Central Java (3,787 units, 166,605 mukim and 132,269 non-mukim); and Aceh (1,177 units, 124,922 mukim and 50,974 non-mukim) [1].
Those pesantren have a meeting point in the basic terms of the establishment (raison d'être), namely the transmission of Islamic teachings which are recorded in the Islamic classic text of scientific disciplines, including comments (sharh) and supercomments (hâshiyah). In Indonesia, the classic text of Islam is known as "kitab kuning" (yellow books) which refers to the yellow paper used when it first arrives in Indonesia from the Middle East [2]. The similarity of the kitab kuning taught in various Islamic boarding schools resulted in homogeneity of life views, culture and religious practices among kiai and santri throughout the archipelago [3].

As a factual example, in determining the fatwa of religious law through the Bahtsul Masa'il Forum, pesantren always make the kitab kuning as a primary reference through the implementation of three 
standard procedures. First, if a problem can be answered with an opinion ( $q a w l ;$ wajh), that opinion is used as a legal fatwa. Second, if a problem can be answered with many opinions (aqwâl; wujûh), the taqrîr jamâ $\hat{\imath}$ (collective decision) is carried out to choose the opinion which is considered the most accurate as a legal fatwa. Third, if a problem is not encountered directly in the kitab kuning text ('ibârah), ilhâq (the contextualization of the kitab kuning) is carried out [4].
Despite the significant position of the kitab kuning, especially for pesantren, research which focus on the kitab kuning are relatively minimal. This reality is found by the researchers when tracing the keyword "kitab kuning" and "yellow book" in 10 reputable journals (accredited by Indonesian Science and Technology Index or Sinta 1 and 2) in a number of State Islamic Religious Colleges (Perguruan Tinggi Keagamaan Islam Negeri; PTKIN) in Table 1.

Table 1. Research Data for the Special Topic of the Yellow Book (Kitab Kuning) in Reputable Journal in State Islamic Religious Colleges (PTKIN)

\begin{tabular}{|c|c|}
\hline Journal & Article \\
\hline $\begin{array}{l}\text { Ulul Albab, UIN Maulana Malik Ibrahim } \\
\text { Malang }\end{array}$ & $\begin{array}{l}\text { Ita Musarrofa, "Analisis Wacana Kritis terhadap Fatwa Bahtsul } \\
\text { Masa'il tentang Perempuan" }\end{array}$ \\
\hline $\begin{array}{l}\text { JIIS (Journal of Indonesian Islam), UIN } \\
\text { Sunan Ampel Surabaya }\end{array}$ & $\begin{array}{l}\text { lbnu Burdah, "Ṭarîqah al-Tarjamah al-Waẓîfiyyah al-Mu'jamiyyah al- } \\
\text { Mu'allaqah" }\end{array}$ \\
\hline \multirow{2}{*}{$\begin{array}{l}\text { Studia Islamika, UIN Syarif Hidayatullah } \\
\text { Jakarta }\end{array}$} & $\begin{array}{l}\text { Ervan Nurtawab, "The Decline of Traditional Learning Methods in } \\
\text { Changing Indonesia:Trends of Bandongan-Kitab Readings in } \\
\text { Pesantrens" }\end{array}$ \\
\hline & $\begin{array}{l}\text { Affandi Mochtar, "Mulâḥaz̧ah 'Âmmah ‘an al-Kutub al-Șafrâ' fî al- } \\
\text { Ma'âhid al-Dîniyyah" }\end{array}$ \\
\hline Walisongo, UIN Walisongo Semarang & $\begin{array}{l}\text { Muhamad Jaeni, "The Nationalism of Javanese Muslim Clerics: } \\
\text { Study on Nationalism Discourse of Kitabs by Kiais of North Coast of } \\
\text { Central Java in the XIX-XX Centuries" }\end{array}$ \\
\hline $\begin{array}{l}\text { Ushuluddin, UIN Sultan Syarif Kasim } \\
\text { Riau }\end{array}$ & $\begin{array}{l}\text { Muhammad Rikza Muqtada, "The Teaching of Religious Moderation } \\
\text { in the Arba'in Hadith of Mahfuzh al-Tarmasi and the Arba'in Hadith of } \\
\text { Hasyim Ash'ari" }\end{array}$ \\
\hline $\begin{array}{l}\text { Al-Jami'ah, UIN Sunan Kalijaga } \\
\text { Yogyakarta }\end{array}$ & - \\
\hline Samarah, UIN Ar-Raniry Aceh & - \\
\hline $\begin{array}{l}\text { Jurnal Pendidikan Islam, UIN Sunan } \\
\text { Gunung Djati Bandung }\end{array}$ & - \\
\hline $\begin{array}{l}\text { IJIMS (Indonesian Journal of Islam and } \\
\text { Muslim Societies), IAIN Salatiga }\end{array}$ & - \\
\hline $\begin{array}{l}\text { QIJIS (Qudus International Journal of } \\
\text { Islamic Studies), STAIN Kudus }\end{array}$ & - \\
\hline
\end{tabular}

Based on data in Table 1, the following two conclusions can be drawn:

The first one is the lack of research on the special topic of the kitab kuning published in a reputable journal which is accredited Sinta 1 and 2. Ironically, the orientalist Martin van Bruinessen is the one who so intensely produces a written paper related to the special topic of the kitab kuning, for examples: a) a book entitled "Kitab Kuning, Pesantren dan Tarekat: Tradisi-Tradisi Islam di Indonesia”, Bandung: Mizan, 1995; b) Book Chapter entitled "Pesantren and Kitab Kuning: Maintenance and Continuation of a Tradition of Religious Learning", in Wolfgang Marschall (ed.), Texts from the Islands. Oral and Written Traditions of Indonesia and the Malay World, Berne: University of Berne, 1994: 121-145; c) Book Chapter entitled "Kitab Kuning dan Perempuan, Perempuan dan Kitab Kuning" in Lies M. Marcoes-Natsir \& Johan Hendrik Meuleman (ed.), Wanita Islam Indonesia dalam
Kajian Tekstual dan Kontekstual, Jakarta: INIS, 1993: 165-174; d) Book Chapter titled "Traditions for the Future: The Reconstruction of Traditionalist Discourse Within NU", in Greg Barton and Greg Feelery (eds.), Nahdlatul Ulama, Traditional Islam and Modernity in Indonesia, Clayton: Monash Asia Institute, 1996: 163 -189; e) An article entitled "Kitab Kuning: Books in Arabic Script Used in the Pesantren Milieu", Bijdragen Tot de Taal-, Land-en Volkenkunde 146 (1990): 226-269.

Second, research on the special topic of the kitab kuning is dominated by an educational perspective which is related to either the learning methods or the contents of the kitab kuning. In this case, such examples of the kitab kuning research which only relate to the learning method are both the research by Burdah (2011) [5], which highlights the Utawi Iki Iku method or the hanging translation (terjemah gandul) method to interpret the kitab kuning in the Pesantren, 
and Nurtawab's Research (2019) [6] which examines the bandongan method in the recitation of the kitab kuning. In the case of the kitab kuning research which only relate to the contents of the kitab kuning are Jaeni's research (2020) [7] which examines the values of nationalism in the kitab kuning, and a research conducted by Muqtada (2019) [8] which competes the moderate thinking of KH. Mahfuzh al-Tarmasi and KH. Hasyim Asy'ari. Moreover, Mochtar's research (1996) [9] is like a general reviewer related to the kitab kuning treasury and Musarrofa research (2017) [10] which discussed the function of the kitab kuning as a primary reference in the Bahtsul Masa'il forum.

Those two above facts have implication for this paper significance to examine the kitab kuning from the perspective of historical development in Indonesia by using philology analysis techniques which include codicology and textology. Codikology has something to do with the ins and outs of the physical script of the kitab kuning, like its writing media. Textology deals with the text contents of the kitab kuning, such as disciplines. Therefore, since this paper is able to enrich scientific research on the special topic of the kitab kuning, it is strongly hoped that it is published in a scientific journal of a reputable publication.

\section{DISCUSSION}

This paper is a library research with a qualitative approach. The data sources are in the form of such literature like books, articles, essays, opinions, news, information or lecture material scattered in various offline and online media, which are relevant to the topic of the development history of the kitab kuning in Indonesia and written by both the Muslim experts as insider and non-Muslim experts as outsider.

The research data was analyzed based on a philology perspective. In this context, researchers refer to the online philology lecture delivered by Otong Sulaeman via YouTube on the "Otong Sulaeman" account. Broadly speaking, philology has two main dimensions. First is codicology or manuscript study which is concrete. Second, textology or text study which is abstract [11].

In detail, codikology includes 18 topics: 1) title of manuscript; 2) the script number (such as the script number in the national library); 3) script material (including writing media); 4) watermark (to know the estimated year of publication); 5) manuscript storage; 6) the origin of the script (grant, purchase, copy); 7) the state of the script (intact, not intact, good, damaged); 8) the size of the script (written with a size of centimeters, such as $17.5 \mathrm{~cm} \times 21.5 \mathrm{~cm})$; 9) manuscript thickness (number of pages); 10) number of lines in each page (including letter size; space); 11) letters or writing system (type, size, ink color, language); 12) text form (prose, poetry); 13) text function (expressing ideas, binding knowledge, communicating ideas, giving responses); 14) the manuscript function (such as the Muṣhaf al-Qur'an as a requirement for the procession of taking the presidential oath); 15) writer (author, muallif) and copyist (scribe, warrâq); 16) history of writing and copying (usually seen in colofon); 17) illustrations (images related to the contents of the script); 18) illumination (picture as a mere decoration).

Textology covers 4 main topics: 1) text criticism related to single and plural manuscripts; 2) text edition, both related to script errors that include: lakuna (there are words or sentences that are exceeded); substitution (word replacement); addition (for letters or syllables); omissions (unspoken letters or syllables); interpolation (inserted words); substitution-interpolation; dittography (repetition of syllables or the same word); metathesis (sound sequences exchange or typo); Or related to the value of a text for people in terms of pragmatic, reception aesthetics, reception and intertextuality dynamics; Including a work must be produced from cultural space, not a vacuum one; 3 ) transliteration (writing system scriftness), such as Latin script to Arabic script in the form of Arab-Pegon or vice versa; and the word absorption, both through the adoption process (take it completely); adaptation (taking the meaning of foreign words, then adjusted the spelling); translation and creations (take basic concepts then change them creatively); 4) translation (transition of meaning or message) related to source text, source language, target text, target language; translation accuracy based on understanding of translators and supported language editors and content editors; and a good form of translation, namely natural (the text translated is not realized by the readers) and effective (correct, saving, careful, logical, parallel, according to culture).

\section{THE DEVELOPMENT HISTORY OF KITAB KUNING BASED ON CODICOLOGY PERSPECTIVE}

The 18 topics of codicology which are used as the theoretical perspective can be simplified into three main topics related to the development history of the kitab kuning in Indonesia. First is the kitab kuning text and script identity. Second is the text and script function of kitab kuning. Third is the authors-copyists and writing-copying of kitab kuning. 


\subsection{Kitab Kuning Text and Script Identity} 3.1.1. Book Titles and Scientific Disciplines

Historian experts have difficulty to find data related to kitab kuning used by pesantren in the early growth: at the time of Sunan Maulana Malik Ibrahim (d. 1419 M). Yet, during the Sunan Giri period, there was a little information. According to Pesantren Luhur, Sunan Giri teaches the Qur'an, Hadith and 'Sittina' book that contains worship law, especially prayers. In the period of Demak (mid- $16^{\text {th }}$ century), pesantren taught the basics of Islamic teachings through the book of Ushul Nem Bis, which was a single handwritten book containing 6 books starting with the sentence of Bismi Allâh al-Rahmân al-Rahîm, the work of Samarkand or Uzbekistan scholars (Sunan Ibrahim Asmaraqandi). Pesantren also teach the book of Tafsîr al-Jalâlayn by Jalâl al-dîn al-Mahallî and Jalâl al-dîn al-Suyûtịi; Suluk Sunan Bonang, Suluk Sunan Kalijaga and Wasita Jati Sunan Geseng in the form of a hand-written dictate. In the $18^{\text {th }}$ century, the pesantren in Mataram had used the kitab kuning of Taqrîb by Abû Shujâ' and Bidâyah al-Hidâyah by Imâm al-Ghazâlî [12].

Starting from the $19^{\text {th }}$ century to the $20^{\text {th }}$ century, the kitab kuning studied in pesantren is increasingly varied both in terms of book titles and disciplines. For example, according to Bruinessen, in the $19^{\text {th }}$ century, the pesantren only used Tafsîr al-Jalâlayn. In the $20^{\text {th }}$ century, there were ten of the books of Arabic, Malay, Java and Indonesian tafsîr. In terms of discipline, in the $19^{\text {th }}$ century, the Books of Hadith, târîkh (Islamic history), manțiq (logic), uṣ̂ul al-Fiqh and falak (Islamic astronomy) were not mentioned at all by Berg. Then the five disciplines developed in the $20^{\text {th }}$ century [13].

In the $21^{\text {st }}$ century, there were more and more pesantren used "white books" (kitab putih; al-kutub al- 'așriyyah) as a reference, specifically the books of contemporary scholars whose writing methods follow modern rules and cross madhhabs. One of the examples is the book of al-Fiqh al-Islamî wa Adillatuhu by Wahbah al-Zuhaylî which is recognized as such a Mu'tabar (trusted) Book by pesantren scholars during the $31^{\text {st }}$ Nahdlatul Ulama (NU) Congress in Boyolali in 2004 that it can be used as a reference in the National Level of Bahtsul Masa'il [14].

The above explanation shows that the development history of the kitab kuning in Indonesia since the $16^{\text {th }}$ to $21^{\text {st }}$ century had a consistent improvement in terms of variations in book titles and disciplines.

\subsubsection{Writing Media and Characteristics of the Yellow Books}

Bruinessen said that when he first arrived in Indonesia from the Middle East, the kitab kuning used yellow paper as its writing media [15]. The use of paper as writing media can be tracked in the history of Islamic civilization globally.

According to Hitti, until the beginning of the $3^{\text {rd }}$ century Hijriyah $(\mathrm{H})$, the written media which is commonly used is parchment (from animal skin) and papyrus. Then in the $3^{\text {rd }}$ century $\mathrm{H}$, precisely in 751 $\mathrm{AD}$, some Chinese prisoners introduced the art of paper making from flax, linen or flax fabrics. The paper industry, then, developed which first initiated in Samarkand then spread to Iraq. In 794 AD $\left(8^{\text {th }}\right.$ century), the first paper factory stood in Baghdad. Paper was used for writing state official documents in the Caliph Harun al-Rashid period. At the end of the $10^{\text {th }}$ century, paper replaced parchment and papyrus in all regions of Muslims [16].

"Arabic paper" or "Islamic paper" which was widely used for writing various documents and books has led to the Arabic standardization and cultural transitions from oral to the writing. In the end, it increases literacy figures, dissemination of knowledge systems and human resource quality. In the context of kitab kuning, paper exported from China, which was made of mulberry trees, used as a material for the writing of Arabic manuscripts written in the range of years $721 / 722$ to $780 \mathrm{AM}$. The first book published manually was the work of al-Râzî in the $9^{\text {th }}$ century, using three materials, namely papyrus, parchment and paper. Ibn al-Nâdhim, one of the $10^{\text {th }}$ century bibliographicians, collected a list of books and scripts written by using paper and ink [17].

The paper used for printing Islamic books was initially yellow as the chemical technology had not been able to produce white paper. Therefore, Islamic books were printed using yellow paper. Therefore, the Islamic books are now known as a kitab kuning though there are currently many Islamic books printed with white paper. The yellow colour has a number of advantages, such as not dazzling the eyes and the mention of the kitab kuning suggests special characteristics attached to it [18].

The characteristics of the kitab kuning include the paper length and width which is around $26 \mathrm{~cm}$ [19] not combined as a whole but is bound by a separated referred to the koras term. In other words, every kitab kuning consists of several koras, while each koras contains around 8 to 20 pages. Thus, when participating in the recitation, the santri (pesantren's 
students) just need to bring such a neccessary koras that they do not need to bring all the koras [20].

The famous kitab kuning publishers in Indonesia are: Al-Hidayah, Salim Nabhan (Surabaya), Lirboyo Press (Kediri), Al-Turats Al-Islami (Jombang), Menara Kudus (Kudus), Toha Putra (Semarang), AlMisriyya (Cirebon), Maktabah At-Turmusy Litturots (Depok) and Dar Al-Kutub Al-Islamiyah (Jakarta). However, the majority of published yellow books are reprint from original books published in Mecca, Cairo or Beirut, such as Dâr al-Kutub, Dâr al-Fikr, Dâr alMinhâj [21].

In addition, the characteristics of the kitab kuning can be seen from the period of time. There is a kitab kuning labeled as a classic book (kitâb almuqaddimah; al-turâth) which is compiled before the $19^{\text {th }}$ century $\mathrm{M}$; and the modern book (kitâb al'așriyyah) which is compiled after the $19^{\text {th }}$ century M. According to Tebuireng PDP team in the Fawait (2015), the characteristic of the kitâb al-muqaddimah cover: a) It does not have punctuation (commas, point, question mark); b) It does not use paragraphs, but the writing systematics from general to specifics, such as the kitâb, bâb, fașl, far', tanbîh and tatimmah. While the typical characteristics of kitâb al-'așriyyah include: a) using punctuation that helps understanding; b) The contents of the book are the results of literary studies that refer to many references [22].

Other distinctions found are: a) kitâb al- 'așriyyah have a table of contents, footnote and reference, which is unlike the kitâb al-muqaddimah; b) kitâb al'așriyyah are equipped with such harakat (vocalization) that it is easy to read, compared to the kitâb al-muqaddimah which is without harakat (gundul); c) kitâb al- 'așriyyah are generally printed on white paper, while kitâb al-muqaddimah are generally printed on yellow paper.

Along with the development of technology, there is a writing media transition from paper to paperless. The yellow book is served in paperless form, such as e-books spread across various online and offline media (generally .pdf format), software (such as al-Maktabah al-Shâmilah), to the special application of the kitab kuning that can be downloaded via a smartphone like PlayStore and AppStore.

\subsection{The Function of the Text and Script of Kitab Kuning}

In principle, Islamic teachings are contained in two sources. First, the source of the revelation is in the form of the Qur'an and Hadith which is absolute, eternal and cannot be changed. This category is called normative Islam (Islam normatif). Second is Ijtihâd's source in the form of a kitab or book of Islamic experts, which is relative, temporary and can be changed. This category is called historical Islam (Islam historis) [23]. From here, it can be understood that the function of the kitab kuning is the elaboration of the meaning of the Qur'an and Hadith based on the results of the Ijtihâd experts.

Specifically, Mochtar stated that in the $16^{\text {th }}$ and $17^{\text {th }}$ centuries, the kitab kuning was positioned as a $d a$ 'wah reference. At the beginning of the $18^{\text {th }}$ century, kitab kuning functioned as a course in the pesantren [24]. In the $19^{\text {th }}$ century, kitab kuning was increasingly stable as a pesantren curriculum. Then in the $20^{\text {th }}$ to $21^{\text {st }}$ centuries, kitab kuning developed in the academic world more massively. Among other things, it functions as a lecture reference in college and primary reference forum Bahtsul Masa'il.

Moreover, kitab kuning has a significant role on a national scale, especially related to legislation. There are at least two factual evidence. First, kitab kuning is a source of formal law in court forums and fatwas. For example, when Sultan Iskandar Muda (d. 1636) ordered the Kingdom of Aceh Darussalam in the $17^{\text {th }}$ century M (1607-1636 AD), the kitab kuning, which was written by Nuruddin al-Raniri (d. 1658) entitled al-șirât al-mustaqîm, was used as a handle of Muslims in Aceh and other regions in Indonesia related to the fiqh of Shâfi' 1 i Madhhab. Second, the kitab kuning is a source of national legal material. For example, the kitab kuning became one of the sources of preparing laws used in Indonesia such as the Marriage Law No. 14 of 1974 and the Law of the Religious Court No. 7 of 1989 [25].

In responding to national issues in the community, since the past, the Indonesian Ulema Council (MUI) not only has been using the Qur'an, Hadith, Uș̂l alFiqh and Fiqh rules as the foundation of the law fatwa issued but also using the kitab kuning consistently. For example, MUI Fatwa No 02 Year 2021 About Vaccine Products Covid-19 from Sinovac Life Sciences, Co. Ltd. China and PT Biofarma, which are declared so suci and halal that they can be used, by referring to the five kitab kuning, namely Sahîh al-Bukhârî by Ibn Battâl; Tuhfah al-Muhtâj by Ibn Hâjar al-Haytamî; Rawḍh al-Ṭâlibîn by Imâm al-Nawâwî; Tahdhîb alAthar by Imâm al-Ṭabârî and Irshâd al-Sârî ilâ Sharh Sahîh al-Bukhârî by al-Qaștalânî [26].

\subsection{Writer-Copyist and Writing-Copying of Kitab Kuning Scripts}

Dahlan (2018) said that the majority kitab kuning emerged after the Book of al-Muwattâ' by Imâm Mâlik and al-Umm by Imâm al-Shafi'î. In summary, kitab kuning in the sense of the kitâb mutaqaddimah (classic book), was written by Mujtahid Madhhab and 
Mujtahid Muntașib in the $10^{\text {th }}$ century M to $19^{\text {th }} \mathrm{M}$. The kitab kuning written in the $20^{\text {th }}$ century $\mathrm{M}$ was more precisely called the kitâb muta'akkhirah (modern book), like the book written by Shaykh Ahmad Khatib Minangkabau (d. 1915), KH. Mahfuzh Termas (d. 1919-20) and KH. Hasyim Asy'ari (d. 1947) [27]. Whereas according to the Tebuireng PDP team, the classic book is a work of scholars before the $19^{\text {th }}$ century $\mathrm{M}$, while the modern book is a work of scholars after the $19^{\text {th }}$ century M [28].

However, the researchers of Islamic boarding schools (pesantren) have a general understanding that kitab kuning is an Islamic book written in Arabic by classical scholars both from the Middle East and Indonesia before the $17^{\text {th }}$ century M (Mochtar, 1996). Futhermore, the authors of the kitab kuning come from various regions of Islam, such as: India (Shaykh Zayn al-Dîn al-Malîbârî: the author of Fath al-Mu 'în); Egypt (Shaykh Zakariyyâ al-Anșârî: the author of Fath $a l$-Wahhâb); Andalusia or Spain (Imâm Ibn Mâlik: the author of Alfiyyah Ibn Mâlik); Samarkand or Uzbekistan (Imâm al-Bukhârî: the author of Șahîh alBukhârî); etc.

Next, there was a transmission of Islamic sciences through the kitab kuning of the Middle East (especially Mecca-Medina) to Indonesia carried out by leading scholars [29]. The leading scholars (ulama) from Indonesia did not only teach the kitab kuning written by non-Indonesian writers but also wrote the work of kitab kuning independently. Among the leading scholars of the $16^{\text {th }}$ century $M$ and $17^{\text {th }} M$ were Hamzah al-Fansuri (Asrâr al- 'Ârifîn), Syamsuddin alSumatrani (Jawhar al-Haqâ'iq), Yusuf al-Makassari (Safinah al-Najâh). In the $18^{\text {th }}$ century M, there were Abdus Shamad al-Palimbangi (Hidâyah al-Sâlikîn) and Muhammad Arsyad al-Banjari (Sabîl alMuhtadîn). In the $19^{\text {th }}$ century M, there were Ahmad Khatib al-Minangkabawi (al-Jawâhir al-Naqiyyah), Mahfuz al-Tarmasi (Kifâyat al-Mustafid) and Imam Nawawi al-Bantani (Nihâyah al-Zayn). In the $20^{\text {th }}$ century M, there were KH. Hasyim Asy'ari (Risâlah Ahl al-Sunnah wa al-Jamâ 'ah), KH. Bisri Mustofa (alIbrîz), KH. Ihsan Jampes (Sirâj al-Ṭâlibîn). In the $21^{\text {st }}$ century, there were KH. Sahal Mahfudh (Tarîqah alHuṣûl), KH. Maimun Zubair (al-'Ulamâ' alMujaddidûn) and KH. M. Afifudin Dimyathi (Jam 'al'Abîr fì Kutub al-Tafsîr).

The transmission of Islamic science through kitab kuning conducted by figures who are educated in the holy land of Mecca-Medina is immortalized in popular terms used to mention the learning activities of kitab kuning, namely "mengaji (recitation)". According to Cak Nur in Amrizal (2018), the recitation is a form of active Javanese verb of "kaji" from the word "hajj".
As a result, mengaji means "follow in the hajj people": learning Islam in Arabic [30].

\section{THE DEVELOPMENT HISTORY OF KITAB KUNING IN THE PERSPECTIVE OF TEXTOLOGY}

\subsection{Kitab Kuning Text Criticism}

Text criticism includes a single and plural script. If the kitab kuning only has one version of the script, it is called a single script. If the kitab kuning has many script versions, it is called a plural script. At present, the majority of the kitab kuning include plural scripts due to the various versions according to the large number of publishers.

Different publishers might have either different formats of published manuscripts or even different texts. For example, the book of Ihyâ' 'Ulûm al-Dîn which was published by Dâr al-Minhâj in Jeddah Saudi Arabia in 2011 uses the exclusive 8 volume format and equipped with such punctuation including vocalization at the end of the word ( $i$ 'râb) that it is relatively easier to read. While the Book of Ihyâ' 'Ulûm al-Dîn, published by Toha Putra in Semarang Indonesia, which is without the year of publication, uses the 4 volume format and equipped with punctuation but there is no vocalization at the end of the word (harakat). Somewhat similar to the publication of the Fathul 'Ulum Kediri Indonesia, which is without the year of publication, uses the 4 volume format, minimal punctuation and without vocalization, but accompanied by the meaning of gandul translation.

One of the text disrepancies was found by KH. Thobary Syadzily who identified tahrîf in the Book of al-Ajurûmiyyah, precisely Nazm: it is read "Bi-Jâhi Muhammad" which connotes to the Messenger of Allah and replaced with the "Bi-hubbi Muhammad" which connotes to love to the Prophet Muhammad [31]. In the context of the philology, this text disrepancy deals with the text edition category since the copyist and publisher have substituted or replaced text.

As the kitab kuning has many versions, readers need to apply the criticism of the plural text in order to know the most accurate publication of the kitab kuning among the other publications. Moreover, if reading the kitab kuning published by publishers affiliated with the wahhabi, as has been proven by the above tahrîf case, because the understanding of the wahhabi often contradicts the understanding of pesantren in Indonesia. 


\subsection{Kitab Kuning Text Edition}

The existence of the kitab kuning from time to time shows that kitab kuning has a pragmatic value for the Indonesian. In addition, the use of kitab kuning as learning material and core curriculum in pesantren also reflects reception aesthetics. Kitab kuning is well received by experts and educated people, especially the kiai who is the caregiver of pesantren in Indonesia.

Toto Edi et al develop an encyclopedia that covers all the daras books in the form of a kitab kuning taught in various Salafiyah Islamic boarding schools in Indonesia, which are categorized into seven disciplines as has been summarized by researchers in the following table 2 [32].

Table 2. Disciplines and Kitab Kuning Titles in Indonesia Pesantren

\begin{tabular}{|c|c|c|}
\hline No & Disciplines & Titles of the Kitab Kuning \\
\hline 1 & $\begin{array}{l}\text { al-Qur'an, Tajwîd, Tafsîr } \\
\text { \& 'Ulûm al-Tafsîr }\end{array}$ & $\begin{array}{l}\text { Hidâyah al-Șibyân, Tuhfah al-Afâl, Fath al-Aqfâl, Miftâh al- } \\
\text { Suhûlah, Tafsîr al-Jalâlayn, Tafsîr Ibn Kathîr, Tafsîr Muhammad } \\
\text { 'Abduh, Tafsîr al-Munîr, Tafsîr al-Qurțîbî̀, Tafsîr al-Marâghî, al- } \\
\text { Itqân fì 'Ulûm al-Qur'ân, Zubdah al-Itqân fî 'Ulûm al-Qur'ân, al- } \\
\text { Tibyân fî̀ 'Ulûm al-Qur'ân, Fayḍ al-Khabîr wa Khulașah al- } \\
\text { Taqrîr, Mabâhîth fì 'Ulûm al-Qur'ân. }\end{array}$ \\
\hline 2 & Hadith \& 'Ulûm al-Hadith & 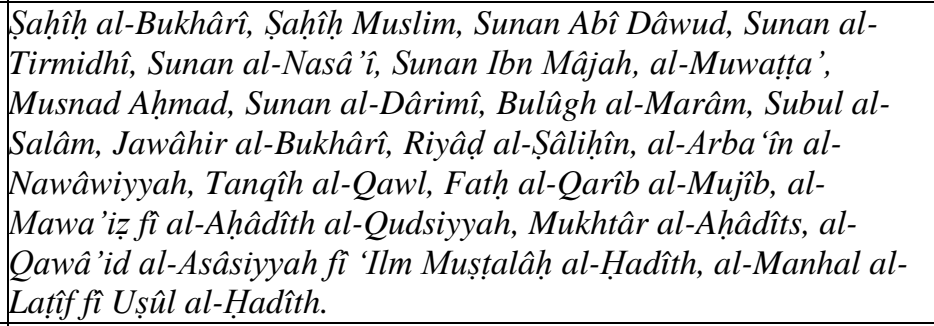 \\
\hline 3 & Tawhî̀ \& 'Aqîdah & 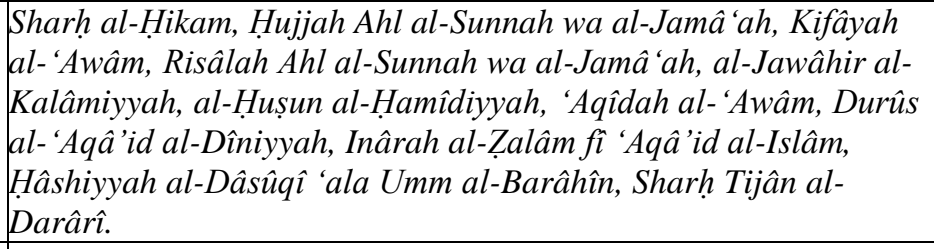 \\
\hline 4 & $\begin{array}{l}\text { Fiqh, Ușûl al-Fiqh \& } \\
\text { (Qawâ'id al-Fiqhiyyah) }\end{array}$ & 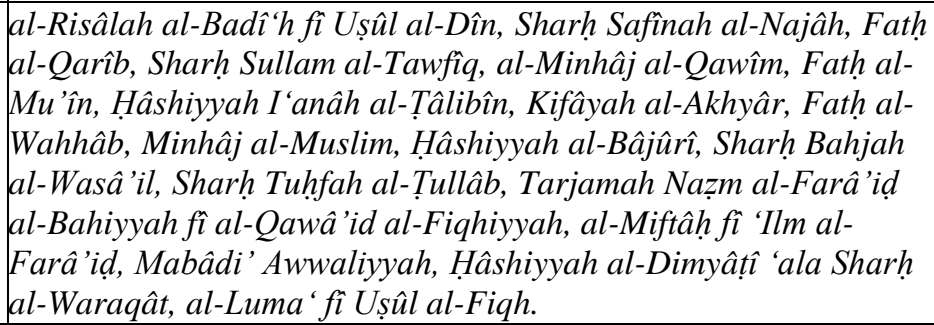 \\
\hline 5 & Akhlâq \& Taṣawwuf & 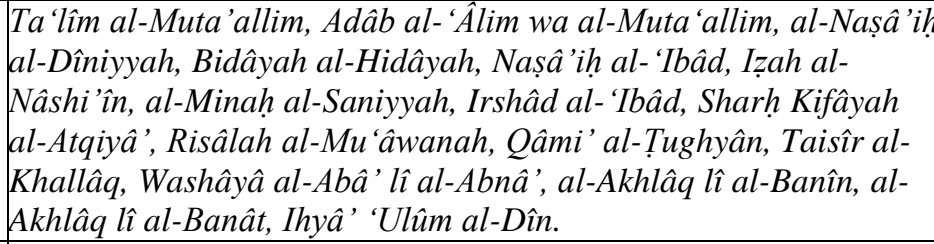 \\
\hline 6 & $\begin{array}{l}\text { Naḥw, Sarf, Balâghah \& } \\
\text { Manțîq }\end{array}$ & 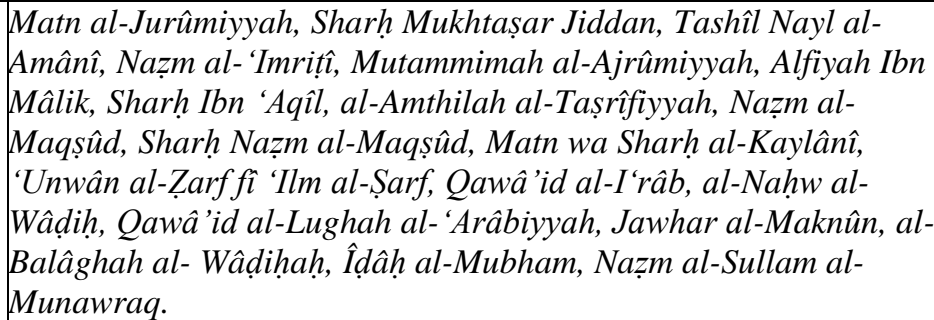 \\
\hline
\end{tabular}




\begin{tabular}{|l|l|l|}
\hline 7 & Târîkh \& Falâq & $\begin{array}{l}\text { Khulâșah Nûr al-Yaqîn, Durûs al-Tarîkh al-Islâmî, al-Durûs al- } \\
\text { Falâqiyyah. }\end{array}$ \\
\hline
\end{tabular}

Various titles of kitab kuning and disciplines presented in Table 2 represent reception aesthetics of pesantren leaders in Indonesia. In philology theory, the more aesthetics of receptions received by the script or text, the more qualified the text is.

However, there is a reception dynamics in the pesantren against kitab kuning. For example, in traditional or salaf pesantren (such as Lirboyo), kitab kuning is examined intensively; While in pesantren that have a formal institution such as Tebuireng, kitab kuning is still studied but not intensively like a salaf pesantren. Whereas in modern or khalaf pesantren such as Gontor, kitab kuning could no longer be studied as it was replaced with dictates or modules compiled by the teaching board [33].

The reception dynamics are also seen in the use of kitab kuning that were previously not studied in pesantren. For example, many pesantren that use the book of al-Tadhhîb fî Adillah Matn al-Ghâyah wa alTaqrîb by Musțafâ Dîb al-Baghâ, for reviewing the dalîl of The Qur'an and Hadith which underlie the Book of al-Taqrib by Abu Shujâ'. This matter cannot be separated from the increasing phenomenon of the needs and criticism of the community to the al-Qur'an and Hadith that underload religious practices, not just based on the kitab kuning.

\subsection{Transliteration and Translation of Kitab Kuning}

Kitab kuning is also called kitab gundul, because it is written without such harakat that it is difficult to understand by readers who do not master Arabic. To make it easier for understanding, the gandul translation method is applied (al-Tarjamah alMu'allaqah; the translation hangs under the main text). The language used includes Javanese, Madura, Sundanese and Malay [34], in accordance with the main language used in pesantren despite all of the Arabic scripts. Thus, this method does not only translates the kitab kuning but also also transliterates the language of the archipelago (Java, Madura, Sunda, Malay) into the Arabic script which is known as Pegon.

The above reason has led to the kitab kuning format which is given the meaning of gandul. On the island of Java, especially East Java, kitab kuning which is given the meaning of gandul, is popularly called the Kitab Kuning of "Pesantren Petuk" because it was first introduced by Pesantren Hidayatut Thulab located in Petuk hamlet, Puhrubuh village, Semen district, Kediri regency, East Java Province. At least there are 148 book titles given the meaning of gandul. The popular ones are al-Ajurûmiyah, al-Arba în Nawâwî, and Fath al-Mu'în [35].

According to Bruinessen in Burdah (2011), around the $16^{\text {th }}$ century $\mathrm{M}$, a number of kitab kuning were found to be translated into Javanese and Malay with the gandul method, including: a) A book on marriage law (munâkahât); b) Qașîdah Burdah by al-Bûșirî; c) al-Tamhîd fî Bayân al-Tamhîd by Abu Syakur; d) alTaqrîb by Abû Shujâ‘ [36].

The pioneer of the translation activity of the kitab kuning in general, which began in the $16^{\text {th }}$ century, was Syaikh Abdul Rauf al-Singkili (1615-1693 AD) (Saridewi, 2016). That is through the book of interpretation of the Qur'an entitled Turjumân Qur'ân which translates the Qur'an into Malay with Arabic script (Pegon). For example, when interpreting alFâtihah's chapter, al-Singkili writes:

$$
\text { اين سورة الفاتحة يائت توجه ايات ... }
$$

"Ini Surat al-Fatihah yaitu tujuh ayat" (This is al-

Fâtihah's chapter, which is seven verses) [37].

The quotation of Turjumân Qur'ân does not only reflect to the translation but also the transliteration of Malay and Latin script into Arabic language and script.

Furthermore, the translation activities of the kitab kuning are growing rapidly, especially translations into Indonesian and Latin script. For example: KH.Sahal Mahfudz and KH. Mustofa Bisri translated the Book of Maws $\hat{u}^{\prime}$ ah al-Ijmâ' published by Firdaus Library in Jakarta in 1987 with the title of Ensiklopedi Ijma'.

Therefore, one of the reserachers, Rosidin, enlivens the translation activity of the kitab kuning into Indonesian. That is translating KH. Hasyim Asy'ari which is published in the form of books: a) Pendidikan Karakter ala Pesantren (Adâb al-'Alim wa alMuta 'allim); b) Fiqih Munakahat Praktis (Dau' alMiṣbâh); c) Inti Fiqih Haji dan 'Umrah (al-Manâsik al-Ṣughrâ); d) Koreksi Peringatan Maulid Nabi SAW (Tanbihât al-Wâjibât); e) Risalah Aswaja: Dari Pemikiran, Doktrin hingga Model Ideal Gerakan Keagamaan (Risâlah Ahl al-Sunnah wa al-Jamâ'ah).

\section{CONCLUSION}

The contribution of this paper is to open the development history of the kitab kuning in Indonesia based on a philology perspective. The implication of this paper is to invite academics, especially 
researchers, to review the topic of the kitab kuning more intensively based on various scientific perspectives (inter-, multi-and and trans-disciplinary).

The combination of library research, field and development (R\&D) using a qualitative and quantitative approach can be used massively to explore the kitab kuning more and more as it still has minimum attention. It is hoped that the high attention from academic society toward the kitab kuning has a positive impact on the quality and quantity of Islamic education, especially for the Islamic boarding schools (pesantren) which are the Indonesian Islamic education institution (indigenous) spread around the archipelago area.

\section{REFERENCES}

[1] PDPP, "Statistik Data Pondok Pesantren," 1402 2021. [Online]. Available: https://ditpdpontren.kemenag.go.id/pdpp/statisti $\mathrm{k}$.

[2] M. v. Bruinessen, "Pesantren and Kitab Kuning: Maintenance and Continuation of a Tradition of Religious Learning," in Texts from the Islands. Oral and Written Traditions of Indonesia and the Malay World, Berne, University of Berne, 1994, pp. 121-145.

[3] Z. Dhofier, Tradisi Pesantren: Studi Pandangan Hidup Kyai dan Visinya Mengenai Masa Depan Indonesia, Jakarta: LP3ES, 2011.

[4] I. Musarrofa, "Analisis Wacana Kritis terhadap Fatwa Bahtsul Masa'il tentang Perempuan," Ulul Albab: Jurnal Studi Islam, vol. 18, no. 2, pp. 135160, 2017.

[5] I. Burdah, "Ṭarîqah al-Tarjamah al-Wazîfiyyah al-Mu'jamiyyah al-Mu'allaqah,” JIIS: Journal of Indonesian Islam, vol. 5, no. 2, pp. 353-376, 2011.

[6] E. Nurtawab, "The Decline of Traditional Learning Methods in Changing Indonesia: Trends of Bandongan-Kitab Readings in Pesantrens," Studia Islamika, vol. 26, no. 3, pp. 511-541, 2019.

[7] M. Jaeni, "The Nationalism of Javanese Muslim Clerics: Study on Nationalism Discourse of Kitabs by Kiais of North Coast of Central Java in the XIX-XX Centuries, Walisongo, vol. 28, no. 1, pp. 29-48, 2020.
[8] M. R. Muqtada, "The Teaching of Religious Moderation in the Arba'in Hadith of Mahfuzh alTarmasi and the Arba'in Hadith of Hasyim Ash'ari," Ushuluddin, vol. 27, no. 2, pp. 121-131, 2019.

[9] A. Mochtar, "Mulâḥaẓah 'Âmmah 'an al-Kutub al-Șafrâ' fî̀ al-Ma'âhid al-Dîniyyah,” Studia Islamika, vol. 3, no. 2, pp. 121-161, 1996.

[10] I. Musarrofa, “Analisis Wacana Kritis terhadap Fatwa Bahtsul Masa'il tentang Perempuan," Ulul Albab: Jurnal Studi Islam, vol. 18, no. 2, pp. 135160, 2017.

[11]O. Sulaeman, ““Filologi 1”, “Tekstologi”, “Tekstologi (2)”, "Kritik Teks Naskah Tunggal dan Jamak", "Edisi Teks 1", "Edisi Teks 2", "Edisi Teks 3: Interteks", “Transliterasi”, "Penerjemahan"," 14-17 February 2021. [Online]. Available: https://www.youtube.com/channel/UCONMNXI f9Fi1Bj-Nhtyh9jg/videos.

[12] M. Qomar, Pesantren: Dari Transformasi Metodologi Menuju Demokratisasi Institusi, Jakarta: Erlangga, 2005, pp. 123-124.

[13] M. Qomar, Pesantren: Dari Transformasi Metodologi Menuju Demokratisasi Institusi, Jakarta: Erlangga, 2005, pp. 124-125.

[14] NU Online, "Perjalanan Kitab Putih Syekh Wahbah Hingga Muktamar NU," 28 February 2015. [Online].

[15] M. v. Bruinessen, "Pesantren and Kitab Kuning: Maintenance and Continuation of a Tradition of Religious Learning," in Texts from the Islands. Oral and Written Traditions of Indonesia and the Malay World, Berne, University of Berne, 1994, pp. 121-145.

[16] P. K. Hitti, History of the Arabs: From the Earliest Times to the Present, London: Macmillan Education, 1989.

[17] M. Shatzmiller, "The Adoption of Paper in the Middle East 700-1300 AD," Journal of the Economic and Social History of the Orient, vol. 61, pp. 1-32, 2018.

[18] M. S. Mahfudh, Nuansa Fiqih Sosial, Yogyakarta: LKiS, 2011.

[19]A. Mochtar, "Mulâḥazah 'Âmmah 'an al-Kutub al-Șafrâ' fî al-Ma‘âhid al-Dîniyyah,” Studia Islamika, vol. 3, no. 2, pp. 121-161, 1996. 
[20] C. Chotimah, "Mobilisasi Intangibles dalam Meningkatkan Kemandirian Ekonomi di Pondok Pesantren (Studi Kasus di Pondok Pesantren Sidogiri Pasuruan)," in Proceeding of 1 st International Conference of Pesantren: Pesantren Management and Development towards Globalization, Malang, 2016.

[21] NUOnline, “Kitab Kuning,” 28 February 2021. [Online].

[22] A. Fawait, "Reinventing Kitab Kuning sebagai Warisan Keilmuan Islam Nusantara," Islamic Akademika, pp. 1-16, 2015.

[23] M. H. Islam, "Islam and Civilization (Analysis Study on the History of Civilization in Islam)," Jurnal Al-Insyiroh: Jurnal Studi Keislaman, vol. 5, no. 1, pp. 22-39, 2019.

[24] A. Mochtar, "Mulâḥaẓah 'Âmmah 'an al-Kutub al-Ṣafrâ' fî al-Ma'âhid al-Dîniyyah,” Studia Islamika, vol. 3, no. 2, pp. 121-161, 1996.

[25] N. Q. \&. Roihanah, "Sketsa Historis Posisi Kitab Kuning dalam Legislasi Hukum Islam di Indonesia," Jurnal Pusaka, vol. 7, pp. 54-68, 2016.

[26] MUI, "Fatwa MUI No 02 Tahun 2021 tentang Produk Vaksin Covid-19 dari Sinovac Life Sciences, Co. Ltd China dan PT Biofarma," 28 February 2021. [Online].

[27] Z. Dahlan, "Khazanah Kitab Kuning: Membangun Sebuah Apresiasi Kritis," Jurnal Ansiru PAI, vol. 3, no. 1, pp. 1-19, 2018.

[28] A. Fawait, "Reinventing Kitab Kuning sebagai Warisan Keilmuan Islam Nusantara," Islamic Akademika, pp. 1-16, 2015.

[29] D. Saridewi, "Masuknya Buku-Buku KeIslaman Timur Tengah ke Indonesia," Jurnal Pustaka Budaya, vol. 3, no. 2, pp. 1-11, 2016.
[30] Amrizal, "Eksistensi Tradisi Kajian Kitab Kuning dalam Lingkup Perubahan Sosial (Studi Kasus di Pesantren Darun Nahdhah, Darel Hikmah dan Babussalam)," Sosial Budaya, vol. 13, no. 1, pp. 73-88, 2016.

[31] M. T. Syadzily, "'Temuan Kitab-Kitab yang Mengalami Perubahan-Perubahan (Tahrif/Distorsi) dan Konsekuensinya," in Halaqah Nasional Kiai Pondok Pesantren Ahlussunnah Wal Jama'ah, Bandung, 2012.

[32]T. Edi, Ensiklopedi Kitab Kuning, Jakarta: Aulia Press, 2007.

[33] A. Nurhayati, "Literatur Keislaman dalam Konteks Pesantren," Pustakaloka, vol. 5, no. 1, pp. 106-124, 2013.

[34] I. Burdah, "Ṭarîqah al-Tarjamah al-Waẓ̂fiyyah al-Mu'jamiyyah al-Mu'allaqah," JIIS: Journal of Indonesian Islam, vol. 5, no. 2, pp. 353-376, 2011.

[35] K. Fatikhin, "Nukilan Kitab Gundul Pondok Petuk Kediri Mendunia," 20 February 2021. [Online].

[36] I. Burdah, "Ṭarîqah al-Tarjamah al-Waẓîfiyyah al-Mu'jamiyyah al-Mu'allaqah,” JIIS: Journal of Indonesian Islam, vol. 5, no. 2, pp. 353-376, 2011.

[37] Muhammad, “Analisis Isi Kitab al-Qur'an alKarim wa Bihamisihi Turjuman al-Mustafid," AlMu'ashirah, vol. 16, no. 1, pp. 12-21, 2019. 